\title{
A DECADE OF INSTITUTIONAL WORK: CONTEXT AND OPPORTUNITIES FOR RESEARCH
}

\author{
Uma década de trabalho institucional: contexto e oportunidades de pesquisa
}

\author{
Felipe de Mattos Zarpelon* \\ Anelise Caon Bittencourt** \\ Kadígia Faccin ${ }^{* * *}$ \\ Alsones Balestrin****
}

\section{ABSTRACT}

The theoretical approach underlying institutional work sustains the understanding of the process through which individuals create, maintain and disrupt institutions. The interest in this approach encouraged the publication of a special issue in the journal Organization Studies in 2013. Lawrence, Leca, and Zilber introduced that special issue with an analysis of this field of study pointing to three avenues to further develop the theoretical approach: a) implementation of methodologies with an emphasis on the individual's experiences; b) development of reflexivity by individuals; and c) commitment to practical contributions. We recall their research to revise the contributions of institutional work and to evaluate how these three avenues have been followed in this field of study. We then suggest an updated research agenda based on phenomena observed in the Brazilian context. Among the contributions of this study, we highlight a) the characteristics of the field of study on institutional work (state-of-the-art); b) central and adjacent themes to institutional work (map of themes); and c) opportunities and trends to further develop research on institutional work.

Keywords: Institutional Work. Institutional Theory. Systematic Review. Research Agenda.

\section{RESUMO}

A lente teórica do trabalho institucional auxilia na compreensão do processo pelo qual indivíduos criam, mantêm ou causam a ruptura de instituições. $O$ interesse por esta abordagem incentivou a publicação de uma edição especial no periódico Organization Studies em 2013, onde Lawrence, Leca e Zilber (2013) introduzem uma análise do campo de estudo com três vetores para a evolução do tema: a) aplicação de metodologias com enfoque nas experiências e vivências do indivíduo; b) desenvolvimento da reflexividade do indivíduo e; c) engajamento das contribuições dos estudos com a prática gerencial. Por conseguinte, esta pesquisa retoma as principais contribuições da lente teórica do trabalho institucional, avalia como esses três vetores vêm sendo tratados no campo de estudos e sugere uma agenda de pesquisa com base em fenômenos observados no contexto brasileiro. Entre as principais contribuições destacam-se: a) características do campo de estudo sobre o Trabalho Institucional (estado da arte); b) temas centrais e adjacentes nos estudos sobre trabalho institucional (mapa conceitual); e c) tendências e oportunidades de estudos futuros sobre o tema.

Palavras-chave: Trabalho Institucional. Teoria Institucional. Revisão Sistemática. Agenda de Pesquisa.

\footnotetext{
* PhD Candidate at the Business Administration Graduation Program at the University of Vale do Rio dos Sinos (Unisinos) - São Leopoldo (RS), Brasil. E-mail: felipemz@edu.unisinos.br. ORCID: 0000-0001-6587-6239

** PhD in Business Administration from the University of Vale do Rio dos Sinos (Unisinos). Professor at the Escola Superior de Propaganda e Marketing (ESPM) - Porto Alegre (RS), Brasil. E-mail: anecaon@hotmail.com. ORCID: 0000-0003-4808-3434

*** PhD in Business Administration from the University of Vale do Rio dos Sinos (Unisinos), and a PhD in Information and Communication Sciences from the Universite de Poitiers (France). Professor at the Business Administration Graduation Program at the University of Vale do Rio dos Sinos (Unisinos) - São Leopoldo (RS), Brasil. E-mail: kadigiaf@unisinos.br. ORCID: 0000-0001-7038-2938

**** PhD in Business Administration from the Federal University of Rio Grande do Sul (UFRS), and a PhD in Information and Communication Sciences from the Universite de Poitiers (France). Professor at the Business Administration Graduation Program at the University of do Vale do Rio dos Sinos (Unisinos) - São Leopoldo (RS), Brasil. E-mail: abalestrin@unisinos.br. ORCID: 0000-0001-6397-1582
} 


\section{INTRODUCTION}

$\mathrm{T}$

he early stages in the development of sciences are characterized by the continual competition between diverse conceptions of distinct natures, which Thomas Kuhn (1962) recognized as paradigms. According to Kuhn (1962), a paradigm is a generally accepted view triggered by scientific achievements that, for some time, provide model problems and solutions for a community of practitioners of a science. In this sense, the theoretical perspective of institutional work, initially proposed by Lawrence and Suddaby (2006), suggests a relevant change in the precepts of traditional institutional theory, especially concerning a more voluntarist vision of the actor in the process of institutional change.

Institutional work serves as a counterpoint to institutional theory by bringing analysis to the level of the actor, in which the individual or organization is responsible for creating, maintaining, or disrupting institutions. Although this is not particularly novel, considering that DiMaggio (1988) called attention to the fact that individuals can act as institutional entrepreneurs, the focus is on the daily practices that govern an institution. According to this theoretical perspective, the promotion of institutional changes requires the institutional work of a broad scope of actors, whether they are those with the necessary resources and abilities to act as entrepreneurs, or those playing roles of support or facilitation in this initiative (LAWRENCE; SUDDABY, 2006).

Since the publication of the seminal text of this theoretical perspective in 2006, institutional work has received increasing attention in organizational studies. Theoretical reviews (LAWRENCE; SUDDABY; LECA, 2009, 2011; SUDDABY, 2010; WILLMOTT, 2011) have helped to build its foundations. Distinct attention is placed on the special edition of the journal Organization Studies of 2013 since it maps the evolution of the theme and proposes new paths. Lawrence, Leca, and Zilber (2013) were the researchers responsible for introducing that edition. As they analyzed the evolution of the theme in the literature, they identified three paths for developing research: a) the use of more efficient methodologies that might evidence the experience of individuals who engage in or are subjected to institutional work; b) the use of reflexivity (the actor's self-awareness about their actions and the context surrounding them) as the central theme for empirical analysis, particularly focusing on how to develop this reflexivity; and c) the development of practical projects that may bring greater managerial contributions and not only theoretical ones.

Although the theoretical perspective has progressively evolved in international journals, the subject is still embryonic in the context of studies regarding the Brazilian context. By the end of 2017, there were fewer than a dozen articles that used the theory in their empirical studies (i.e., JACOMETTI; GONCAVES; DE CASTRO, 2014; SANDER; CUNHA, 2013; LEONEL JUNIOR; CUNHA, 2013; MIRANDA; CALMON, 2016) or articulated it with other lenses of analysis (CORAIOLA et al., 2015; DONELLY, 2010; TURETA; JÚLIO, 2016). A possible reason for the absence of papers using this theoretical perspective lies in the novelty of this approach to Brazilian authors. Therefore, the purpose of this article is to highlight the field of study of institutional work, drawing attention to gaps that may be the object of research, in addition to Brazilian phenomena that might produce rich cases for study. It is worth noting the importance of a study referring to the literature developed until 
now, disseminating this theoretical field and motivating researchers interested in phenomena in the Brazilian context to enter this global research agenda.

With the objective of mapping and positioning future opportunities for research on institutional work, this article uses the claims made by Lawrence, Leca and Zilber (2013) to compose a literature update. Thus, in this study, an analysis of the state-of-the-art of institutional work was performed, seeking to indicate paths for future studies. For this purpose, a systematic review of the literature was carried out based on empirical studies that dealt with institutional work as the central theme, as of 2013. Once the selection criteria were defined, such as databases, journals and search terms, thirty seminal papers were selected for analysis.

The results demonstrate that the initial propositions made by Lawrence, Leca and Zilber (2013) had wide repercussions in this field of study. Although some effort is apparent in the direction of responding to the gaps noted by the authors, there are still opportunities to consolidate the applicability of institutional work, especially as an ideal theoretical lens for studies on innovation, entrepreneurship and organizational changes, in which a particular actor plays a relevant role in the process. Methodologies based on ethnography have proven to be efficacious in evidencing the experiences and motivations of individuals who are engaged in creating, maintaining or disrupting institutions (FINE; HALLETT, 2014; LANDAU; DRORI; TERJESEN, 2014).

Seven sections comprise this paper, including this introduction. In the following section, institutional work as an evolution of institutional theory and its impact on organizational studies is discussed. Next, the methodological procedures used in this literature review are presented. Subsequently, we address the gaps in the field of study on institutional work brought in the studies proposed by Lawrence, Leca and Zilber (2013). Then, the "perceived advances" of the theoretical perspective, since 2013, are presented. In the sixth section, a research agenda based on directions outlined in the literature is introduced. The last section contains the final considerations and suggestions for future work.

\section{INSTITUTIONAL WORK IN THE FIELD OF ORGANIZATIONAL STUDIES}

The organizational framework of institutional theory is based on defining the process of institutionalization of the organization (SELZNICK, 1948). Institutionalization is a longitudinal process in which the experiences and aspirations of individuals within the organization, as well as the interests of small groups and society in general, begin to shape their actions (ZUCKER, 1977). This view is important, as it is the first step toward recognizing that the organization is a reflection of its internal and external environment.

The recognition of this relationship between organizations and their environment leads to the development of a new perspective acknowledged as neo-institutionalism (MEYER; ROWAN, 1977; DIMAGGIO; POWELL, 1983). Under a neo-institutional perspective, organizations are led to adopt practices and procedures institutionalized in society to increase their legitimacy and access to resources, thus ensuring their survival in the environment (MEYER; ROWAN, 1977). 
Neo-institutional theory seeks to understand how relationships end up establishing rules and beliefs that are widespread among all participants in the organizational field (JEPPERSON, 1991). The analysis is basically performed at the organizational and environmental levels and, predominantly, based on a very deterministic view of the actors in relation to their environment. Recent studies in the institutional field advance in direction of a new perspective by placing the actors in a much more voluntarist relation with their environment, that is, addressing the actions of individuals and organizations that incite institutional changes in a given context (LAWRENCE; SUDDABY, 2006).

The focus of institutional work is the daily practices that make it possible to maintain or transform institutions (WILLMOTT, 2011). Practices are carried out by individual or collective actors capable of creating, maintaining or disrupting institutions (LAWRENCE; SUDDABY; LECA, 2011). This perspective is important because it brings the actors as a central element in institutional theory by instituting them as responsible for changing or even maintaining stability in a given institutional context (HWANG; COLYVAS, 2011). Institutional work focuses on the everyday practices and strategies by which individuals and groups of individuals intentionally shape the institutional patterns in which they operate (DOVER; LAWRENCE, 2010), a continuous process that evolves and adapts over time (STYHRE, 2014).

Institutions must be based on social needs and/or beliefs to maintain their legitimacy. There is a risk in the institutional theory of dismissing the rationality of the individuals' choices, giving rise to non-reflexive activity (STYHRE, 2014). Institutional work evolves precisely from this perspective, seeking propositions for the emergence, maintenance, and disruption of institutions by the deliberate agency of individuals. This change is relevant because it positions the individual as the one responsible for the dynamics of institutions (LAWRENCE; SUDDABY; LECA, 2011).

Because of its focus on the individuals' behavior, institutional work intensifies the discussion of the relationship between agency and institutions (LAWRENCE; SUDDABY; LECA, 2009, 2011). The dualism between individual action (human agency) and social structures (institutions) pervades the discussions on the theme, (BATTILANA; D'AUNNO, 2009; DOVER; LAWRENCE, 2010). Although this discussion was initially brought to the institutional theory with the advent of neo-institutionalism (DIMAGGIO; POWELL, 1983), institutional work is responsible for strengthening it. This duality between agent and agency in institutional work indicates the main conceptual elements of this theoretical perspective: institutions, actors, and practices (WILLMOTT, 2011).

\section{METHODS}

Since this paper brings a systematic literature review, it is worth reporting the method adopted before presenting the main findings. As we understood that the theoretical field of institutional work had been gradually evolving in recent years (LAWRENCE; SUDDABY; LECA, 2011), we proposed updating its state-of-the-art with a focus on theoretical-empirical research. Therefore, it was possible to identify its evolution on recurrent issues - such as agent reflexivity - as well as to propose opportunities for future studies. This study combi- 
nes elements of state-of-the-art and scope literature review (JESSON; MATHESON; LACEY, 2011).

The methodological procedures proposed by Seuring and Gold (2012) were adopted, suggesting the need to indicate criteria for paper selection, descriptive analysis, and categories of analysis. The definition of criteria for selecting papers is in line with the central objective of this study: to demonstrate the state-of-the-art of the field of institutional work, pointing to fulfilled demands and persistent gaps. The starting point was to go through the field searching for papers that have already performed some sort of mapping in this sense. The most recent paper we found was the one by Lawrence, Leca, and Zilber (2013), in which they identify recurrent issues, new directions, and neglected themes. Thus, the first delimitation concerns the date of publication: an updated literature mapping should only include papers from 2013-2016.

After this definition, we used search and selection metrics. As a database, we used the Web of Science portal because of its comprehensiveness and international recognition. For the search, we used the term "institutional work". To the database of articles found, we applied the filters year of publication (2013 to 2016), research area (Business Economics) and data sources, which means that only journals classified as "Q1" by the Scimago index were accepted, resulting in 48 papers.

In the third stage of selection, we excluded articles published in the special edition of the journal Organization Studies (issue 38, volume 8) or articles that had already been cited and therefore analyzed in the study carried out by Lawrence, Leca and Zilber (2013). We also excluded purely theoretical articles since one of the claims of Lawrence, Leca and Zilber (2013) is that the studies should demonstrate empirical mechanisms that help to develop the reflexivity of individuals. Only the work of Gill (2014), proposing a methodological discussion, was maintained. Additionally, the authors' third claim was that studies in institutional work should be capable of bringing empirical implications, and in particular, tools that could be used by managers, responding to a historical critique regarding the distance between institutional theories and practical implications (WILLMOTT, 2011; DOVER; LAWRENCE, 2010). Thus, after the third selection stage, the analysis base was consolidated in 30 papers.

Among the chosen papers, it is possible to note the dispersion among some of the journals with the greatest impact on organizational research, demonstrating the interest in the subject of institutional work. In any case, Organization Studies, Organization Science and Journal of Management Studies, all journals with an h index above 100 points, are those with the greatest number of articles in the selected base. From the 30 articles selected, 12 were published in 2013. This may be due to the emphasis given to the topic in publications that helped to establish an understanding of this new way of thinking about institutional implications in organizational life (LAWRENCE; SUDDABY; LECA, 2011) and the request for empirical studies that could broaden the knowledge of the subject (DOVER; LAWRENCE, 2010).

A systematic literature review should base its analysis on pre-defined categories that are capable of maintaining the direction and consistency during this step (SEURING; GOLD, 2012). Thus, we based the central elements of the analysis on the three propositions from Lawrence, Leca and Zilber (2013) for the evolution of the field of study in institutional 
work: a) implementation of methodologies with emphasis on the individual's experiences; $b$ ) development of reflexivity by individuals; and c) commitment to practical contributions. The upcoming section portrays a detailed frame of these propositions.

In addition to the alignment with these three elements, this literature review also sought to highlight the strategies and procedures adopted in this field of knowledge. We acknowledged the methodological strategies applied, the research objectives, field and empirical objects, contributions to practice and theory, and research gaps.

As a subsidy for the analysis, we used the methodological tool of thematic maps, shaped from the keywords that emerged in the database. These maps are important tools to confirm and emphasize the main focuses of previous research on institutional work. A conceptual map is a two-dimensional map in which the terms are positioned in such a way that the distance between them indicates their relationship. In general, the smaller the distance between the terms, the stronger their relation. Co-occurrences determine the relationship between terms. We used these word maps to support the content analysis of the papers, to triangulate the data, and to present more concise propositions.

\section{INITIAL REVIEWS OF THE NEW FIELD OF STUDY}

As a starting point for the study, it is important to understand the main theoretical and methodological concerns highlighted by Lawrence, Leca and Zilber (2013), the pillars that underpinned and motivated this research. The authors have mapped three elements still neglected in institutional work studies. These elements are ultimately related to methodological approaches and procedures, the focus of the analysis, and direction of the study.

The distinction between studies that seek to identify the connections between institutional work and its outcomes and those that seek to understand work itself (LAWRENCE; LECA; ZILBER, 2013) is clear. Knowing the activities and motivations that lead individuals to engage in mundane activities that end up creating, maintaining, or causing institution disruption has always been at the heart of institutional work (LAWRENCE; SUDDABY, 2006; LAWRENCE; SUDDABY; LECA, 2009). However, research on this subject tends to focus much more on the connections between the individual's actions and their intentional consequences, using retrospective approaches based on interviews and documentary data to compose the analysis (LAUREL; ZILBER, 2013). Thus, there is an opportunity to carry out research with methodological approaches that might evidence the experiences of the actors in vivo and in situ (LOCKE, 2011), in addition to their successes and errors in daily repetitions.

A second aspect for the development of knowledge in institutional work concerns the understanding of the effort that institutional work demands. Actors engaged in institutional work tend to be portrayed as experts, given their ability to manipulate their institutional environment, but this approach involves the risk of underestimating the cognitive and emotional efforts required for the actor to develop reflexivity about their actions (LAWRENCE; LECA; ZILBER, 2013). Although such reflexivity is difficult to analyze, especially empirically, research on institutional work should treat it as the central theme of studies; therefore, it is important to highlight how the reflexivity of the actors develops, either through relational 
tools (RAVIOLA; NORBÄCK, 2013) or as a result of environmental issues (LAWRENCE; SUDDABY; LECA, 2009).

The direction of the study is the third aspect raised by Lawrence, Leca and Zilber (2013). Reflecting the initial propositions of institutional work, the individual actor would have the capacity to transform institutions through their routines, acting meticulously and intentionally (LAWRENCE; SUDDABY, 2006), which positions the individual as the engine of institutions and not only as a passive follower of environmental pressures. Institutional work would be a way of transforming realities and mitigating social dysfunctions resulting from institutional pressures. However, this orientation of institutional work as transformative and capable of reducing social inequalities is sparsely evidenced in the empirical studies analyzed by Lawrence, Leca and Zilber (2013). To address this distortion, the authors reinforce the call for research on institutional work that can engage the academic community and connect to practical issues so that it truly becomes a theory with relevant practical implications.

Considering the research gaps noted by the authors, we opted for the triangulation of data. Thus, to validate the findings of Lawrence, Leca and Zilber (2013), a term map was elaborated, based on the co-occurrence of keywords. We searched the Web of Science for all papers that contained the keyword "institutional work". The bibliometric mapping map, Figure 1, was compiled with all the keywords of papers published until 2013. On the map, it is possible to identify the emergence of four clusters. It is important to highlight that, for this analysis, keywords with a minimum of five occurrences in the period were relevant.

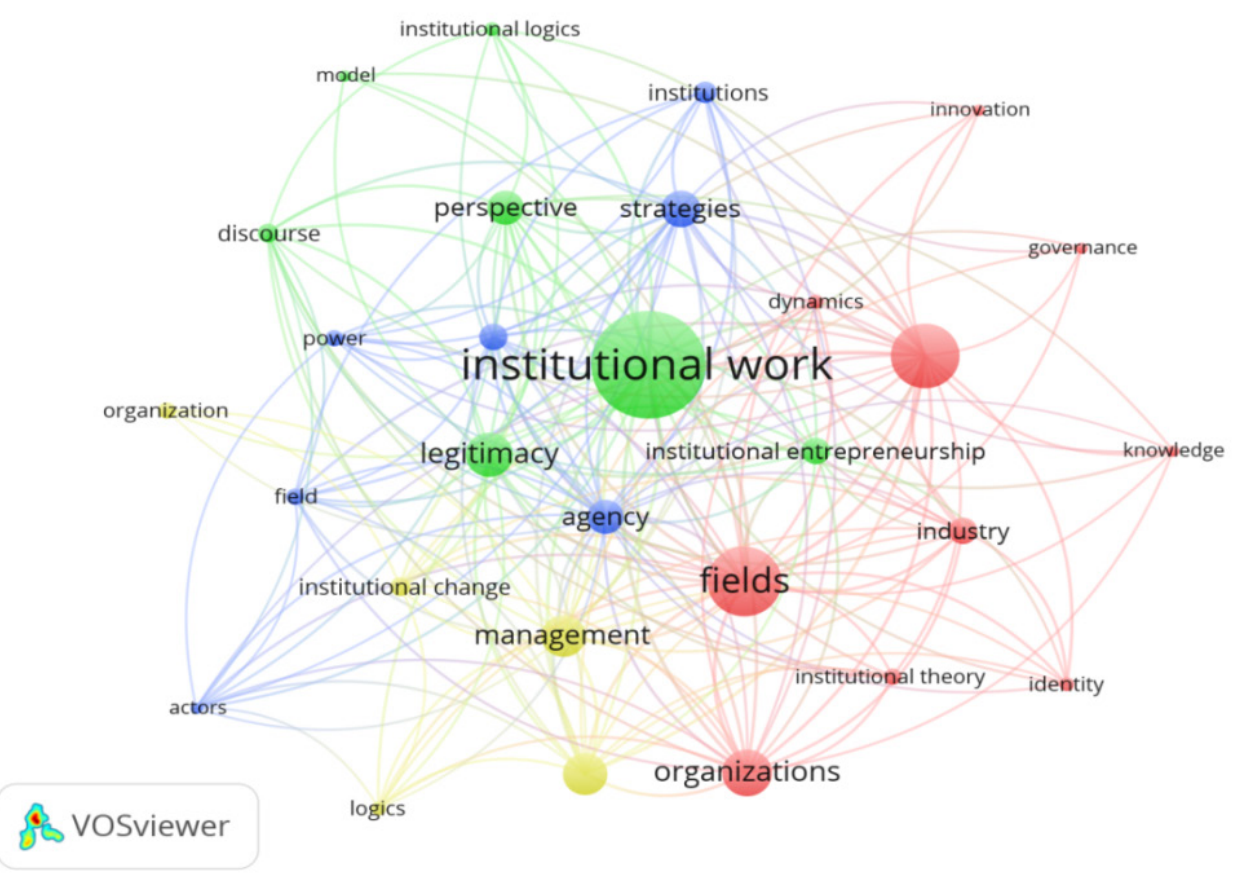

Figure 1 - Bibliometric Mapping with the Evolution of the Thematics - 1945-2013. 
The first cluster, shown in red in the map, is the one with the highest number of associated keywords, acknowledged as the "institutional environment" cluster. This cluster seems to highlight the concentration of studies focused on demonstrating the actor's ability to manipulate their institutional environment, especially when related to the areas of organization and innovation. A representative study of this current, in addition to those already considered by Lawrence, Leca and Zilber (2013) is the study by Gawer and Phillips (2013) that explores the forms of institutional work. This cluster supports the observation made by Lawrence, Leca and Zilber (2013) that the main objective of studies on institutional work is to relate the individual's actions and their environmental consequences.

The second cluster, presented in green, demonstrates the attempt to position institutional work in the field of institutional theory, specifically addressing differences concerning issues such as institutional logic and institutional entrepreneurship. To perform this positioning, the studies use traditional concepts of the theory, such as models and legitimacy, as well as concepts related to individual perspectives, such as discourse.

The third cluster of keywords, presented in blue, concerns issues related to power, strategies, and agency. This cluster of keywords also shows some concerns about the role of the actor. However, in observing the map, it is possible to show that the actor's reflexivity is not yet treated as a relevant theme, supporting the proposition of Lawrence, Leca and Zilber (2013).

The fourth cluster, shown in yellow, still incipient, reveals the characteristic of voluntarism of institutional work again, but bringing the theme to the managerial practice, when relating institutional change to management. The incipience of this cluster makes clear the criticism of Lawrence, Leca and Zilber (2013) regarding the need for more studies that might inform managers about the transformational role of institutional work.

Based on the analysis performed by Lawrence, Leca and Zilber (2013), confirmed by the analysis of keywords, Table 1 presents a synthesis of studies that used the approach of institutional work. The focus of studies from the seminal work in 2006 (LAWRENCE; SUDABBY, 2006) up to the time of academic achievement by Lawrence, Leca and Zilber (2013) was evidenced. We indicate the main articles that are dedicated to each of the approaches cited in the paper from 2013. It was possible to verify that some research gaps stand out despite the scientific development of this approach. In this paper, such shortcomings constitute the acknowledged research opportunities identified in 2013.

Table 1 - Synthesis of Institutional Work Studies and Research Opportunities

\begin{tabular}{|c|c|c|}
\hline Study focus (up to 2013) & Examples of Papers & Opportunities \\
\hline $\begin{array}{l}\text { Studies tend to use retrospective } \\
\text { approaches based on interviews and } \\
\text { documentary data to analyze the } \\
\text { relationship between the individual's } \\
\text { actions and their consequences. }\end{array}$ & $\begin{array}{l}\text { Zietsma and Lawrence } \\
\text { (2010). }\end{array}$ & $\begin{array}{l}\text { Conducting research with methodologi- } \\
\text { cal approaches that might evidence the } \\
\text { experiences of the actors in vivo and in } \\
\text { situ, besides their successes and errors } \\
\text { in daily repetitions. }\end{array}$ \\
\hline
\end{tabular}




\begin{tabular}{|c|c|c|}
\hline Study focus (up to 2013) & Examples of Papers & Opportunities \\
\hline $\begin{array}{l}\text { Actors engaged in institutional work } \\
\text { tend to be portrayed as experts with the } \\
\text { capacity to manipulate their institutional } \\
\text { environment, sometimes underesti- } \\
\text { mating the cognitive and emotional } \\
\text { efforts required for the actors to develop } \\
\text { reflexivity about their actions. }\end{array}$ & $\begin{array}{l}\text { Empson, Cleaver, and } \\
\text { Allen (2013); Singh } \\
\text { and Jayanti (2013); } \\
\text { Gawer and Phillips } \\
\text { (2013). }\end{array}$ & $\begin{array}{l}\text { There is a risk that this approach unde- } \\
\text { restimates the cognitive and emotional } \\
\text { efforts required for the actors to develop } \\
\text { reflexivity about their actions. As it is } \\
\text { difficult to analyze, it is important to } \\
\text { highlight how the reflexivity of the actors } \\
\text { develops, either through relational tools } \\
\text { or environmental issues. }\end{array}$ \\
\hline $\begin{array}{l}\text { Institutional work as a way of trans- } \\
\text { forming realities and mitigating social } \\
\text { dysfunctions resulting from institutional } \\
\text { pressures. }\end{array}$ & $\begin{array}{l}\text { Slager, Gond, and Moon } \\
\text { (2012). }\end{array}$ & $\begin{array}{l}\text { However, this direction of institutional } \\
\text { work as transformative and capable } \\
\text { of reducing social inequalities is not } \\
\text { thoroughly evidenced in empirical } \\
\text { studies. }\end{array}$ \\
\hline
\end{tabular}

Source: Authors.

This table served as a reference for achieving the objectives of this study. We then sought to identify how researchers who have adopted the lens of institutional work for their studies have mobilized efforts to meet these research opportunities.

\section{PROGRESS IN THE FIELD OF STUDY}

As a starting point to analyze the results from the year 2013 onwards, we tried to understand whether the suggestions proposed by Lawrence, Leca, and Zilber (2013) were met in later publications. From this analysis, it is possible to identify a map with the lessons learned and persistent paths that deserve to be explored more deeply. The data are presented and analyzed in the sequence proposed by the authors in the special issue of Organization Studies: methodological strategies, reflexivity of the individual and study direction.

\subsection{METHODOLOGICAL STRATEGIES}

Consistent with the observations of Lawrence, Leca, and Zilber (2013), case study was the methodological strategy predominantly adopted in research on institutional work. Of the 30 papers analyzed, 21 adopt case studies in their definitions of methodological procedures, which is reasonable because of the need to deepen the knowledge and to understand the history that characterizes the institutional work processes (ZIETSMA; LAWRENCE, 2010).

The predominant research questions still show concern about understanding institutional work as a process (i.e., BINZ et al., 2016; GAWER; PHILLIPS, 2013) and as a tool for institutional change (i.e., PAROUTIS; HERACLEOUS, 2013; LAWRENCE; DOVER, 2015). Therefore, it makes sense to choose case studies due to their detailed description and investigation of a specific phenomenon (YIN, 2015). Among these, single case studies are observed more frequently in the analyzed database. Yin (2015) highlights the importance of extreme, representative and unique cases that can elucidate and help to understand a certain theory. Multiple cases, in turn, are advocated by Eisenhardt (1989), among others, 
as particularly important in the process of theoretical construction. Since institutional work is a concept that is still being consolidated, it might be interesting to find other multiple case studies that could show causal relationships in institutional work.

Returning to the guidelines of Lawrence, Leca, and Zilber (2013) on methodologies capable of highlighting the experiences of the individual and responding more clearly about work itself, ethnography seems to be a relevant strategy. Although only five studies have used ethnography in their methodological procedures (FINE; HALLETT, 2014; LANDAU; DRORI; TERJESEN, 2014; HEAPHY, 2013; MCCANN et al., 2013), they are effective in demonstrating the experiences of individuals conducting institutional work. For example, when entering a hospital environment and following the routine of professionals who provide care to patients, Heaphy (2013) was able to build a detailed narrative of how these professionals maintain the expected institutional standards, even in opposition to recurring attempts of transformation.

In another robust study, Landau, Drori, and Terjesen (2014) bring a ten-year longitudinal study based on ethnography. On three occasions, researchers spent time in the field to identify how narratives evolve over time and ultimately influence and legitimize institutional changes. These examples demonstrate the effectiveness of the recommendations made by Lawrence, Leca, and Zilber (2013). The five ethnographic studies identified in the analyzed database highlighted the experiences of individuals conducting the institutional work, revealing problems previously neglected, namely: the role of the group in institutional work (FINE; HALLETT, 2014); narratives as an instrument of legitimization (LANDAU; DRORI; TERJESEN, 2014); motivations that lead individuals to endorse institutional maintenance work (HEAPHY, 2013); the need for alignment between institutional entrepreneurship and institutional work (MCCANN et al., 2013); and an alternative ontology for the understanding of institutions as something that is not stable, but rather something that is "becoming" (BJERREGAARD; JONASSON, 2014).

All of the 30 papers analyzed were empirical. However, at the moment of defining the criteria for inclusion, one of the articles was analyzed under an exception criterion. The article written by Gill (2014) and published in the journal Organizational Research Methods highlights the possibilities of using phenomenology in organizational studies and notes that institutional work requires the specific research patterns that phenomenology could address. Gill (2014) also notes that until the time of the article's publication, no study had used any form of phenomenology as a research methodology when addressing matters related to institutional work. Suddaby (2010, p. 16) suggests that "[...] methodologically if we are to take the ideational aspects of institutions seriously, we need to incorporate interpretive methods that pay attention to the subjective ways in which actors experience institutions." In this sense, phenomenology seems to be a powerful tool for scholars who seek to examine and explore how individuals subjectively experience and give meaning to particular phenomena, such as institutions (GILL, 2014).

\subsection{POSITION OF THE INDIVIDUAL}

The reflexivity of the individual was the central theme in 16 out of the 30 papers analyzed. For this, some studies sought an articulation with other theoretical and methodolo- 
gical perspectives. Deroy and Clegg (2015), for example, bring recursive contingency, based on Luhmann's (1977) theoretical assumptions, to connect two extremes of institutional theory: institutional work (agent) and institutional logic (structure). In doing so, the authors simplify social construction to a process of codification (what is acceptable and what is not) and differentiation (new codifications that challenge previous ones), a situation in which the individual's reflexivity is paramount. The development of such reflexivity occurs over time by processes of differentiation in which the other individuals are led to analyze the same common events using newly proposed codes.

Zundel, Holt, and Cornelissen (2013) use Bateson's (1941) epistemological propositions about regenerative and degenerative cycles of ethos to connect the individual to their reflexivity in institutional theories. Bateson (1941) considers flexibility in the construction of social meanings, which could be a response to the distinction between the individual (actor) and the structure (institution), common in the discussions on institutional work (LAWRENCE; SUDDABY, 2006). Zundel, Holt, and Cornelissen (2013) suggest that this duality diminishes through increased actor reflexivity.

Social tools are also brought as capable of developing the reflexivity of individuals in institutional work. Narratives and discourse can promote reflexivity to legitimize institutional changes (LANDAU; DRORI; TERJESEN, 2014). Boxenbaum (2014) is dedicated to understanding how actors negotiate and justify actions through shared moral "worlds". The author even depicts a comparison between shared moral worlds and institutional logic.

In the same way, physical sites can be used for this purpose (LAWRENCE; DOVER, 2015), as well as awards that can encompass physical and human attributes (MONTEIRO; NICOLINI, 2015) Policies as a structure of rules of conduct, whether public (BINZ et al., 2016) or corporate (KARAM; JAMALI, 2013) can be used to stimulate the individual's awareness of their actions; even social structures or individual experiences can develop their reflexivity (HEAPHY, 2013).

Malsch and Gendron (2013) emphasize the paradox of embedded agency in studies on institutional work. For the authors, it is not clear how an individual can intentionally conduct actions that lead to disrupting institutions that in essence end up shaping their own actions. To do so, the concept of "institutional experimentation" is proposed, according to which the individuals - in being able to disentangle themselves from the institutional structures under which they are placed - find the freedom to be imaginative and innovative (MALSCH; GENDRON, 2013). Some studies, such as the one by Cascio and Luthans (2014), focus on psychological capital as an alternative for individuals to challenge incorrect policies or established beliefs.

Other authors also address reflexivity as a characteristic of the individual to develop his propositions (GOND; BOXENBAUM, 2013; MCCANN et al., 2013). However, they report to which extent this reflexivity might be developed (LAWRENCE; LECA; ZILBER, 2013).

\subsection{IMPLICATIONS OF THE STUDIES}

Concerning the implications of the studies, only 3 out of 30 papers demonstrate concerns about bringing relevant managerial contributions. Albeit superficially, another eight 
articles give indications to practice. The other 19 studies make purely theoretical contributions.

Dolbec and Fischer (2015) show that engaged consumers can become sources of innovation in market dynamics. For this, the authors inform managers of organizations in high consumption markets about a model with four fundamental elements aiming to develop the engagement of their clients: a) the existence of places for interaction between consumers; b) low cost of experimentation; c) observability of experimental behavior; and d) product and technology infrastructure. This model emphasizes the authors' concern about connecting institutional theories with managerial practice (LAWRENCE; LECA; ZILBER, 2013).

In line with the assumption that through institutional work individuals may conduct social transformations (LAWRENCE; SUDDABY; LECA, 2009), Karam and Jamali (2013) identify how corporate social responsibility policies can influence gender equality in the Middle East. In arguing that corporations have this transformational role, the authors suggest a model by which such organizations might align their policies to meet moral and human development problems.

Similarly, Heaphy (2013) addresses changes from a hospital-centered model to a model centered on the patient and human well-being in the United States. At the core of this change is the figure of the patient advocate. Knowing this relationship and the patient's behavior, Heaphy (2013) suggests a model in which the participation of this professional is central to the process of defining conduct policies in American hospitals.

Other studies inform managers about the importance of certain elements in institutional change. Public policies as support to the legitimation of innovation (BINZ et al., 2016), the use of discourse and narrative (PAROUTIS; HERACLEOUS, 2013), or the alignment between actions at the strategic level (institutional entrepreneurship) and at the operational level (institutional work) as drivers of organizational change (MCCANN et al., 2013), are some examples. In time, Koskela-Huotari et al (2016) indicate institutional change as an essential element in innovation in service ecosystems and suggest that managers can develop institutional work to do so.

In this scenario, it is evident that from the triangulation of data with the papers published after 2013, the gaps noted in the seminal article gained attention in the field of study. In summary, considering the research opportunities identified by Lawrence, Leca, and Zilber (2013), the table elaborated from the 2013 review was expanded, presenting papers that explore the lessons learned in a summarized form.

Table 2 - Synthesis of studies and fulfillment of research gaps

\begin{tabular}{lll}
\hline Opportunities highlighted in 2013 & \multicolumn{1}{c}{ Recent Approaches } & Example of studies \\
\hline $\begin{array}{l}\text { Conducting studies with methodolo- } \\
\text { gical approaches that might provide }\end{array}$ & $\begin{array}{l}\text { Studies have used ethnographic and } \\
\text { processual approaches and highlighted }\end{array}$ & Fine and Hallett (2014); \\
evidence of the experiences of the & the importance of phenomenology. & Landau; Drori and Terjesen \\
actors in vivo and in situ in addition & Advances have been made in the & (2014); Heaphy (2013); \\
to their successes and errors in daily & $\begin{array}{l}\text { use of social network analysis and } \\
\text { repetitions. }\end{array}$ & Mccann et al (2013). \\
\hline
\end{tabular}




\begin{tabular}{|c|c|c|}
\hline Study focus (up to 2013) & Examples of Papers & Opportunities \\
\hline $\begin{array}{l}\text { This approach risks underestimating } \\
\text { the cognitive and emotional effort } \\
\text { required for the actor to develop } \\
\text { reflexivity about their actions. } \\
\text { Difficult to analyze, it is important } \\
\text { to highlight how the reflexivity of } \\
\text { the actors develops, either through } \\
\text { relational tools or environmental } \\
\text { issues. }\end{array}$ & $\begin{array}{l}\text { To address the lack of understanding } \\
\text { about reflexivity, some studies have } \\
\text { sought an articulation with other } \\
\text { theoretical and methodological pers- } \\
\text { pectives. Power balance, the paradox of } \\
\text { embedded agency, institutional experi- } \\
\text { mentation and the existence of shared } \\
\text { moral worlds are some of the imminent } \\
\text { explanations in the studies. }\end{array}$ & $\begin{array}{l}\text { Deroy and Clegg (2015); } \\
\text { Lawrence and Dover (2015); } \\
\text { Monteiro and Nicolini (2015); } \\
\text { Binz et al (2016). }\end{array}$ \\
\hline $\begin{array}{l}\text { The direction of institutional work } \\
\text { as transformative and capable of } \\
\text { reducing social inequalities is not } \\
\text { thoroughly evidenced in empirical } \\
\text { studies. }\end{array}$ & $\begin{array}{l}\text { Studies have focused on gender equa- } \\
\text { lity issues or changes in the hospital } \\
\text { model, as well as on institutional } \\
\text { change as an essential element of } \\
\text { innovation. However, none of them has } \\
\text { been able to indicate managerial tools } \\
\text { based on on institutional work. }\end{array}$ & $\begin{array}{l}\text { Dolbec and Fischer (2015); } \\
\text { Karam and Jamali (2013); } \\
\text { Heaphy (2013). }\end{array}$ \\
\hline
\end{tabular}

Source: Authors.

Although the analysis has revealed managerial implications from studies, none is propositive to the point of indicating the elaboration of managerial tools grounded on institutional work. Recommendations have emerged (i.e., GOND; BOXENBAUM, 2013; EMPSON; CLEAVER; ALLEN, 2013), but practical elements to the point of effectively assisting managers have not come into discussion. Therefore, the next chapter proposes an agenda for future research, addressing the main gaps found in the review carried out regarding scope, theory, methodology, and articulation with adjacent themes.

\section{DIRECTIONS FOR FUTURE STUDIES}

Several papers bring recommendations for future research under the institutional work perspective. Mapping these suggestions helps in the development of the field of study, in addition to highlighting topics that have not yet been explored. As a way of grouping and describing these suggestions, we identified four approaches that future research should address: scope, theoretical development, methodological exploration, and adjacent themes. Table 3 summarizes the main suggestions for future research.

Table 3 - Synthesis of gaps highlighted in the database

\begin{tabular}{lll}
\hline \multicolumn{1}{c}{ Approach } & \multicolumn{1}{c}{ Description } & \multicolumn{1}{c}{ Main studies } \\
\hline \multirow{2}{*}{ Scope } & $\begin{array}{l}\text { A set of papers that depict suggestions for change in the } \\
\text { traditional scope of institutional work analysis, either by inclu- } \\
\text { ding hierarchical social levels or by checking for unintended } \\
\text { and adverse effects of using tools (i.e., discourse, materials, } \\
\text { and locations). }\end{array}$ & $\begin{array}{l}\text { Bertels; Hoffman and } \\
\text { Dejordy (2014); Paroutis } \\
\text { and Heracleous (2013); } \\
\text { Monteiro and Nicolini } \\
\text { (2015). }\end{array}$ \\
\hline $\begin{array}{l}\text { Theoretical } \\
\text { development }\end{array}$ & $\begin{array}{l}\text { A set of papers that suggest testing new constructs, such } \\
\text { as recursive contingency, institutional experimentation, and } \\
\text { context work. }\end{array}$ & $\begin{array}{l}\text { Deroy and Clegg (2015); } \\
\text { Malsch and Gendron } \\
\text { (2013); Gond and Boxen- } \\
\text { baum (2013). }\end{array}$ \\
\hline
\end{tabular}




\begin{tabular}{lll}
\hline Approach & \multicolumn{1}{c}{ Description } & \multicolumn{1}{c}{ Main studies } \\
\hline $\begin{array}{l}\text { Methodologi- } \\
\text { cal exploration }\end{array}$ & $\begin{array}{l}\text { A set of papers that suggest new epistemological (i.e., } \\
\text { actor-network theory) or methodological approaches (i.e., } \\
\text { processual method; netnography) applied to studies in institu- } \\
\text { tional work. }\end{array}$ & $\begin{array}{l}\text { Fine and Hallett (2014); } \\
\text { Kozinets (2010); Lawrence } \\
\text { and Dover (2015). }\end{array}$ \\
\hline $\begin{array}{l}\text { Adjacent } \\
\text { themes }\end{array}$ & $\begin{array}{l}\text { A set of papers that suggest deepening the relationship } \\
\text { between institutional work and adjacent themes, such as } \\
\text { innovation and institutional entrepreneurship. }\end{array}$ & $\begin{array}{l}\text { Koskela-Huotari et al } \\
\text { (2016); Mccann et al } \\
\text { (2013). }\end{array}$ \\
\hline
\end{tabular}

Source: Authors.

In line with the objective of positioning future opportunities for researchers interested in Brazilian thematics, this study proposes typical Brazilian phenomena that could potentially be used to respond to the gaps identified in the database of these 30 papers. These phenomena have unique characteristics to effectively contribute to the development of the theoretical perspective (YIN, 2015)

Studies suggesting future research focused on a new scope indicate: a) broadening the object of analysis; b) unfolding the analyzed propositions; or c) establishing new relations between object and theory. Monteiro and Nicolini (2015), for example, analyze how material elements, in the form of prizes, can positively influence institutional work. Therefore, they suggest that future research analyze the negative aspect of material elements s on institutional work.

A set of papers are propositive to the point of indicating the existence of new constructs or even theoretical perspectives complementary to institutional work. These, in turn, suggest that future research test these constructs in new empirical observations. Malsch and Gendron (2013) introduce the concept of institutional experimentation and put it to the test by suggesting assessment of their propositions in upcoming research.

The methodological approach, on the other hand, suggests the adoption of new procedures that come from different methodologies for the analysis of the same phenomenon. Zundel, Holt, and Cornelissen (2013) analyze the duality of agency and structure, characteristic of institutional work, under the epistemological perspective of Bateson (1941). The authors suggest that other nontraditional methodological approaches may also highlight the effects of this duality on institutional work.

Finally, some authors suggest the development of generic themes, such as the alignment between the different hierarchical levels in institutional work (MCCANN et al., 2013) and innovation as a process of institutional change (KOSKELA-HUOTARI et al., 2016). Differently from the theoretical approach, the authors here do not necessarily propose new constructs, but indicate gaps in the further development of the phenomena analyzed by them.

It is worth mentioning that an article can address suggestions concerning more than one approach; however, for discussion purposes, only the main indication for future research was highlighted, that is, the indication that was directly connected to the propositions of the article. 


\subsection{SCOPE AND PHENOMENA}

egarding new scopes, Bertels, Hoffman, and Dejordy (2014) analyze the social position of each organization in the institutional work that challenges environmental policies in the USA. They suggest an analysis of the level of imbrication of the individual in the community, rather than focusing only on the social position. Therefore, questions concerning social capital and the structure of social relations (GRANOVETTER, 1985; BURT, 2000) could indicate the actor's ability to promote institutional change. In the same ecosystem of services, the Brazilian Health System (Sistema Único de Saúde - SUS) brings together governmental, public, philanthropic and private organizations with the objective of disseminating and guaranteeing universal access to health in Brazil. The complexity of relationships within this environment forms a unique community (BARBOSA, 2013; BARBOSA; MALIK, 2015), being a potential phenomenon to be analyzed in response to this gap.

Similarly, Binz et al (2016) indicate that processes of legitimation of innovation might be better understood by narrowing the scope of analysis to a specialized group of actors (such as academia, legislators, and consumers). Thus, studies could indicate the impact of social construction on the actions of institutional work. The Brazilian national innovation system understood through the role of governmental agencies, supporting organizations, universities, and research centers constitutes a relevant research phenomenon (SILVEIRA et al., 2016; CRUZ; SOUZA, 2014).

The effect of the hierarchical level of actors on the forms and effectiveness of institutional work also needs to be better understood. It is not yet clear how the actions of institutional work vary depending on the level of formal authority of each professional. In time, the motivations that lead individuals to engage in actions to sustain the institution may be distinct depending on their hierarchical position (HEAPHY, 2013). Upcoming research may focus on these positional differentiations within or across organizations to elucidate the behavior of institutional work.

Regarding the implementation of tools, authors differ on the need to position the scope of analysis. After identifying four dimensions of discourse as a tool for institutional conduction - functional, contextual, identity and metaphorical - Paroutis and Heracleous (2013) suggest that future studies focus on the relationships between these dimensions. Monteiro and Nicolini (2015), on the other hand, suggest a reversal in the tooling logic. Why not analyze the unintended counter-effects of tools on institutional work (MONTEIRO; NICOLINI, 2015)? In this sense, the paradox of the struggle against corruption in Brazil is brought to discussion. While institutional mechanisms to control and combat corruption have been progressively implemented (SILVA et al., 2017), the increasing levels in the perception of corruption by the population are remarkable (INTERNATIONAL TRANSPARENCY, 2017).

\subsection{COMPLEMENTARY THEORIES}

Four papers in the database propose new constructs and theoretical approaches. Recursive contingency, shared agency, and institutional experimentation are constructs developed in response to the recurring problem of agency present in the discussions on 
institutional work (LAWRENCE; SUDDABY, 2006; WILLMOTT, 2011). A fourth construct context work - is proposed as an evolution in relation to the typification of institutional work. For each construct, the authors suggest tests and further theoretical development.

It is worth reminding that recursive contingency is based on the theoretical precepts of Luhmann (1977) on codification and differentiation. Flexibility is key to this new construct that is used to demonstrate that two extremes of institutional theory - institutional work and institutional logic - are not antagonistic or established in a duality of behavior, but have limits that are porous and sometimes may overlap, based on the reflexivity of the individual (DEROY; CLEGG, 2015) The authors' request, therefore, is that future research adopts recursive contingency to understand the processes of reproduction of institutions over time and also the unexpected collapse of institutional structures. From the perspective of institutional reproduction, the "Brazilian way" ("jeitinho brasileiro" ${ }^{1}$ ), as a characteristic practice of interpersonal relationships, is mapped as a relevant phenomenon (PEDROSO; MASSUKADO-NAKATANI; MUSSI, 2009) However, from the perspective of the unexpected collapse of institutional structures, the abrupt rupture of the Brazilian shipbuilding program (SILVA; MARTINS, 2007), as well as the economic recession of 2015-2016 (ROLDÃO et al., 2018) provide unique characteristics to be analyzed.

In line with the discussion on agency in institutional work, Empson, Cleaver, and Allen (2013) identify as unlikely the notion that isolated individuals may conduct institutional changes. On the other hand, individuals use shared agency, that is, the action is taken together, to seek the synergy of individuals in different positions in the community (EMPSON; CLEAVER; ALLEN, 2013). We suggest deepening shared agency in institutional work to better understand how coalitions develop within the organization and how the members of such coalitions explore the different sources of social position to engage in institutional work. It is also important to look at how shared agency crosses the boundaries of the organization. The participation of society in the construction of public policies through the coproduction of public services, such as the Participatory Budget (Orçamento Participativo) (SOUZA; SILVA, 2017) and the Portal e-cidadania, shows the collective agency of groups of individuals.

Given the above observations, the paradox of embedded agency (BATTILANA; D'AUNNO, 2009) raises the question of whether individuals within institutional structures would be able to experience the necessary strangeness to challenge these very structures. Malsch and Gendron (2013) argue that if daily actions, such as those defended in institutional work, are incapable of overcoming this problem, then periods and places of experimentation of new institutional practices are necessary. The authors suggest that the concept of institutional experimentation must be empirically deepened and assessed since it opens space for innovation, imagination, and reflexivity in the transformation of the field (MALSCH; GENDRON, 2013)

In time, when analyzing how institutions are transposed from one place to another, Gond and Boxenbaum (2013) suggest the work of contextualization. This typification of institutional work is a specific effort to promote technical, cultural and political adjustments of the institution to its new context. Contextual work is typified as: a) filtering; b) repurposing;

1. Cultural traces of Brazilian behavior that deals with the way which difficulties can be solved without contradicting norms and laws (VIEIRA; COSTA; BARBOSA, 1982). 
and c) coupling. The authors then suggest that the three types of contextualization work can be used to explore how individuals promote the circulation of business practices that have emerged across institutional boundaries. The process of the direct investment of Brazilian companies abroad and the consequent transposition of the national management culture (RIBEIRO et al., 2017) presents itself as a phenomenon that could be analyzed under the perspective of contextualization work.

Within the Brazilian scope of publication, Tureta and Júlio (2016) explore how institutional work can complement the approach of strategy in practice once it considers changes in the institutional environment and how strategic practices may leverage them. In summary, Tureta and Júlio (2016) highlight the opportunity to advance in new constructs identified within the lens of institutional work and to include it as a perspective of analysis for Brazilian phenomena.

\subsection{METHODOLOGICAL APPROACHES}

The use of new epistemological approaches or methodological procedures has been highlighted in the database as an opportunity for the evolution of the field of institutional work. Processual approaches, focus on the actions of individuals, and the analysis of behavioral and emotional reactions are among the suggestions. Although processual analysis has traditionally been part of the methodological procedures of research in institutional work (ZIETSMA; LAWRENCE, 2010), there is a recurrent gap for the actions of the individual to be evidenced through a process. The adoption of a processual approach implies the inclusion of notions of time and space in positioning events and actors (LANGLEY, 1999). However, there is a risk in research that focuses on secondary data to delimit actors and events in a process, since they do not cover the characteristic features of the individual (ZUNDEL; HOLT; CORNELISSEN, 2013).

Methodologies that may encompass behaviors and reactions both at the group level and at the individual level are also encouraged. Fine and Hallett (2014) suggest that new methodologies in institutional theory seek to understand the power of group interaction and shared memories regarding organizational life. Dolbec and Fisher (2015) highlight netnography (KOZINETS, 2010) as a path for methodological development in this sense. Other techniques or other epistemological approaches may contribute to overcoming this impasse.

As for non-traditional epistemological approaches, Lawrence and Dover (2015) suggest that actor-network theory (LATOUR, 1996) might illuminate the relationship between humans and material elements in institutional work. Donelly (2010) links the actor-network theory with institutional work, arguing that such a composition provides a way to bring life to practices associated with institutionalization. Future research can relate the notion of places containing, mediating or connecting institutional work to the notion of people and objects inserted in an actor-network context, where humans and nonhumans are "actants" (LAWRENCE; DOVER, 2015). 


\subsection{ADJACENT THEMES}

Intrinsic to the suggestions for future studies is the notion of deepening research. However, for purposes of delimitation and discussion, we will focus on three out of the 30 papers, which indicate the deepening of a generic theme, without necessarily proposing a new theory. Innovation as a process of institutional change, definition of roles for the diffusion of institutional practices, and the alignment between institutional work and institutional entrepreneurship are observed here as a guideline for future research.

Koskela-Huotari et al (2016) examine innovation as a process that unfolds through changes in the institutional arrangements that govern practices of resource integration in service ecosystems. Ultimately, the authors suggest that institutional work is a consequence (intentional or otherwise) of innovation movements. The deepening, then, is due to the recursive relation between innovation and institutional work. Additionally, new research may highlight the emergent and unpredictable nature of innovation as a process of reconfiguring the institutional structure of the service ecosystem (KOSKELA-HUOTARI et al., 2016). The Brazilian agricultural sector has suffered recurrent influences towards the technological development of crops (SZNITOWSKI; SOUZA, 2016) Due to the traditional nature of the Brazilian productive system, the innovation observed in this field points to a phenomenon of institutional change. For this reason, technological innovation in Brazilian agribusiness is a potential phenomenon for analysis.

In a new attempt to connect institutional logic and action, Singh and Jayanti (2013) identify a processual and recursive framework between logic, function, and practice, highlighting the connecting characteristic of the functions defined by the organization. This framework, however, does not evidence generic mechanisms of the function. The authors invite new researchers to answer which mechanisms could assist in the proposition of these functions and which mechanisms could help in the adjustment between logic and institutional practice.

Mccann et al (2013) distinguish actions of institutional entrepreneurship (DIMAGGIO, 1988) and institutional work (LAWRENCE; SUDDABY, 2006) in a metaphor of formal and informal actions, respectively. Thus, institutional entrepreneurship may not be enough to fulfill institutional change, since work at the informal level might be in contradiction. The suggestion is to deepen the knowledge about the forms of alignment between these two concepts of institutional action (MCCANN et al., 2013).

In the recent publication of Hampel, Lawrence, and Tracey (2017, p.574), the authors portray the lack of attention to what they call "big institutions", that is, "[...] institutionalized practices, beliefs, and norms that cut across fields and seem to endure over long periods of time". In this sense, they suggest studies that address issues that also have an impact outside academia and meet global demands and challenges, such as global health, gender inequality, access to drinking water, peace and security, refugees and migration. The consequences arising from this context represent not only a global challenge, but a combination of institutionalized practices, beliefs, values, and assumptions linked to complex combinations of institutional work, as well as potential solutions to the damage they currently cause (HAMPEL; LAWRENCE; TRACEY, 2017). Studies based on Brazilian cases 
could promote not only an analysis of such phenomena but also act in a propositional way, in response to the authors' calls.

Finally, Table 4 summarizes the mapping of research for the elaboration of this paper, serving as a picture of the field of study of institutional work, in the past, present and with a view towards future perspectives.

Table 4 - Synthesis of focus on institutional work studies across time

\begin{tabular}{|c|c|c|}
\hline Focus up to 2013 & Focus from 2013 to 2016 & New Opportunities \\
\hline $\begin{array}{l}\text { Studies tend to use retrospective } \\
\text { approaches based on interviews } \\
\text { and documentary data to analyze } \\
\text { the relationship between the } \\
\text { in-dividual's actions and their } \\
\text { con-sequences. }\end{array}$ & $\begin{array}{l}\text { Focus is on conducting case } \\
\text { studies, but with perspectives of } \\
\text { change with the implementa-tion } \\
\text { of methodological ap-proaches } \\
\text { that evidence the experience of } \\
\text { the actors, such as ethnography } \\
\text { and netnogra-phy. }\end{array}$ & $\begin{array}{l}\text { Implementation of new metho- } \\
\text { dological approaches based on } \\
\text { processes that high-light behavior } \\
\text { both at the level of the in-dividual } \\
\text { and the group. Adoption of } \\
\text { epis-temological approaches that } \\
\text { consider the interaction between } \\
\text { human and material agents, such } \\
\text { as actor-network theory. }\end{array}$ \\
\hline $\begin{array}{l}\text { Actors engaged in institutional } \\
\text { work tend to be portrayed as } \\
\text { experts with the capacity to } \\
\text { ma-nipulate their institutional } \\
\text { envi-ronment, sometimes unde- } \\
\text { resti-mating the cognitive and } \\
\text { emo-tional efforts required for the } \\
\text { actor to develop reflexivity about } \\
\text { their actions. }\end{array}$ & $\begin{array}{l}\text { Studies tend to focus on institu- } \\
\text {-tional work in the development } \\
\text { of reflexivity of actors throughout } \\
\text { the development process of new } \\
\text { institutions. }\end{array}$ & $\begin{array}{l}\text { Analysis of the efforts made by } \\
\text { the actors as a result of their } \\
\text { position in the commu-nity. } \\
\text { Implementation of new constructs } \\
\text { that bring the development of } \\
\text { the individ-ual's reflexivity to the } \\
\text { center of discus-sions: recursive } \\
\text { contingency and institu-tional } \\
\text { experimentation. }\end{array}$ \\
\hline $\begin{array}{l}\text { Institutional work as a way of } \\
\text { transforming realities and miti-ga- } \\
\text { ting social dysfunctions result-ing } \\
\text { from institutional pressures. }\end{array}$ & $\begin{array}{l}\text { Recurrent focus on the } \\
\text { devel-opment of analytical } \\
\text { and de-scriptive studies, with } \\
\text { little evidence of implications for } \\
\text { practice. }\end{array}$ & $\begin{array}{l}\text { The lack of prescriptive studies } \\
\text { that might inform practitioners } \\
\text { about the possibilities of social } \\
\text { transformation by institutional } \\
\text { work remains. }\end{array}$ \\
\hline
\end{tabular}

Source: Authors.

Thus, despite the latest advances regarding innovative and convincing research on institutional work, important issues remain poorly or superficially examined. New research opportunities point to the use of processual approaches or even new epistemology to conduct the studies, analyses whose scope focuses the efforts undertaken by the actors as a result of their social position, and even prescriptive studies that might connect practices to challenges of social transformation through institutional work. Phenomena observed in the Brazilian context demonstrate a potential response to these gaps, calling for a Brazilian agenda of organizational research under the institutional work perspective.

\section{FINAL REMARKS}

Except for more effective managerial implications, the claims from Lawrence, Leca, and Zilber (2013) seem to have been addressed. Although the methodological strategy most commonly adopted still is the case study, the fact that four papers based their studies on 
ethnographies underscores the concern about understanding, in depth, the action, that is, the "work" itself, led by individuals who build, maintain or challenge institutions. Ethnographies are capable of providing meaningful insights about group interactions regarding local knowledge, cultural commitment and the sense of belonging (FINE; HALLETT, 2014), which are essential to the analysis of action. However, ethnography requires that researchers have the time to be immersed in the field (HAMMERSLEY; ATKINSON, 2007). For this reason, perhaps, there are still few studies that have applied this methodology to institutional work.

We also observed unusual methodological procedures, such as historical analysis (MARTINEZ-MOYANO; MCCAFFREY; OLIVA, 2013) and social networks analysis (BERTELS; HOFFMAN; DEJORDY, 2014). Both, however, are insufficient to provide evidence of the experiences of individuals in conducting institutional work. The netnography technique (KOZINETS, 2010), on the other hand, adjusts the precepts of traditional ethnography to the context of virtual communities. This technique has proven to be quite efficient in mapping the behavior of individuals in situations of collective coexistence in virtual environments (DOLBEC; FISCHER, 2015) and therefore could be used in future studies on institutional work.

Regarding agent reflexivity, the concerns of Lawrence, Leca, and Zilber (2013) seem to be addressed. Although most of the articles still do not treat reflexivity as the central theme of the analysis, 11 out of the 30 papers do. The researchers use unusual theoretical or methodological perspectives in institutional studies, such as actor-network theory (LATOUR, 1996), Luhman's (1977) coding and differentiation cycles, and Bateson's (1941) epistemological flexibility.

Henceforth, the paradox of embedded agency (BATTILANA; D'AUNNO, 2009), at the heart of which lies the reflexivity of the individual, is not yet completely solved. Three new theoretical propositions arise from studies in the database trying to somehow respond to this problem: recursive contingency, shared agency, and institutional experimentation. Apart from testing their propositions, theoretically deepening these new constructs can be a fertile way for the further development of the field.

Among the aspects raised by Lawrence, Leca, and Zilber (2013), the managerial contribution of studies about institutional work is the one that still needs to be stressed and further developed. The theoretical contributions of the studies are still predominant and, in most publications, the only outstanding implications. Institutional work, while basing the responsibility of institutional movements on the individual, still follows the tradition of institutional studies and distances itself from practice (DOVER; LAWRENCE, 2010; LAWRENCE; LECA; ZILBER, 2013). It is questioned, then, whether the researchers investigating institutional work would not be imprisoned in a research structure which is incapable of providing managers with tools that can help them to develop their businesses. A structure that reproduces the focus on theoretical propositions and distances the theory from practice. The fact is, the challenge of developing effective managerial implications from research and turning institutional work into a tool to connect institutional theory and managerial practice remains.

Typical Brazilian phenomena, such as the National Health System (Sistema Único de Saúde - SUS), platforms of public service coproduction, anti-corruption policies, the economic recession of 2015-2016, and technological innovation in agribusiness, provide 
subsidies for research to effectively respond to a significant number of the gaps noted in this study. Therefore, this paper not only alerts about recurrent gaps in the international literature, but also portrays a research agenda that allows researchers who are interested in the Brazilian context to contribute to the constitution of the state-of-the art on the theoretical perspective of institutional work.

\section{REFERENCES}

BARBOSA, E. C. 25 anos do sistema único de saúde: conquistas e desafios. Revista de Gestão em Sistemas de Saúde, v. 2, n. 2, p. 85-102, 2013.

BARBOSA, A. P.; MALIK, A. M. Desafios na organização de parcerias público-privadas em saúde no Brasil. Análise de projetos estruturados entre janeiro de 2010 e março de 2014. Revista de Administração Pública, v. 49, n. 5, p. 1143-1165, 2015.

BATESON, G. Experiments in thinking about observed ethnological material. Philosophy of Science, v. 8, n. 1, p. 53-68, 1941.

BATTILANA, J.; D'AUNNO, T. Institutional work and the paradox of embedded agency. In: LAWRENCE, T.; SUDDABY, R.; LECA, B. Institutional work: Actors and agency in institutional studies of organizations, p. 31-58, 2009.

BERTELS, S.; HOFFMAN, A. J.; DEJORDY, R. The varied work of challenger movements: Identifying challenger roles in the US environmental movement. Organization Studies, v. 35, n. 8, p. 1171-1210, 2014.

BINZ, C. et al. The thorny road to technology legitimation-Institutional work for potable water reuse in California. Technological Forecasting and Social Change, v. 103, p. 249263, 2016.

BJERREGAARD, T.; JONASSON, C. Managing unstable institutional contradictions: The work of becoming. Organization Studies, v. 35, n. 10, p. 1507-1536, 2014.

BOXENBAUM, E. Toward a situated stance in organizational institutionalism: Contributions from French pragmatist sociology theory. Journal of Management Inquiry, v. 23, n. 3, p. 319-323, 2014.

BURT, R.S. The network structure of social capital. Research in organizational behavior, v. 22, p. 345-423, 2000.

CASCIO, W. F.; LUTHANS, F. Reflections on the metamorphosis at Robben Island: The role of institutional work and positive psychological capital. Journal of Management Inquiry, $v$. 23, n. 1, p. 51-67, 2014.

CORAIOLA, D. et al. Conciliando agência e contexto na dinâmica da mudança institucional. Cadernos EBAPE. BR, v. 13, n. 4, p. 701-726, 2015.

CRUZ, H. N.; SOUZA, R. F. Sistema Nacional de Inovação e a Lei da Inovação: análise comparativa entre o Bayh-Dole Act e a Lei da Inovação Tecnológica. Revista de Administração e Inovação, v. 11, n. 4, p. 329-354, 2014. 
DEROY, X.; CLEGG, S. Back in the USSR: Introducing recursive contingency into institutional theory. Organization Studies, v. 36, n. 1, p. 73-90, 2015.

DIMAGGIO, P. Interest and Agency in Institutional Theory. In: ZUCKER, L.G (ed.) Research on Institutional Patterns: Environment and Culture. Cambridge: Ballinger Publishing Co. 1988, v. 1, p. 3-22, 1988.

DIMAGGIO, P.; POWELL, W. W. The iron cage revisited: Collective rationality and institutional isomorphism in organizational fields. American Sociological Review, v. 48, n. 2, p. 147-160, 1983.

DOLBEC, P.; FISCHER, E. Refashioning a field? Connected consumers and institutional dynamics in markets. Journal of Consumer Research, v. 41, n. 6, p. 1447-1468, 2015.

DOVER, G.; LAWRENCE, T. B. A gap year for institutional theory: Integrating the study of institutional work and participatory action research. Journal of Management Inquiry, v. 19, n. 4, p. 305-316, 2010.

EISENHARDT, K. M. Building theories from case study research. Academy of management review, v. 14, n. 4, p. 532-550, 1989.

EMPSON, L.; CLEAVER, I.; ALLEN, J. Managing partners and management professionals: Institutional work dyads in professional partnerships. Journal of Management Studies, v. 50, n. 5, p. 808-844, 2013.

FINE, G. A.; HALLETT, T. Group cultures and the everyday life of organizations: Interaction orders and meso-analysis. Organization Studies, v. 35, n. 12, p. 1773-1792, 2014.

GAWER, A.; PHILLIPS, N. Institutional work as logics shift: The case of Intel's transformation to platform leader. Organization Studies, v. 34, n. 8, p. 1035-1071, 2013.

GILL, M.J. The possibilities of phenomenology for organizational research. Organizational Research Methods, v. 17, n. 2, p. 118-137, 2014.

GOND, J-P.; BOXENBAUM, E. The glocalization of responsible investment: Contextualization work in France and Quebec. Journal of Business Ethics, p. 707-721, 2013.

GRANOVETTER, M. Economic action and social structure: The problem of embeddedness. American journal of sociology, v. 91, n. 3, p. 481-510, 1985.

HAMMERSLEY, M.; ATKINSON, P. Ethnography: Principles in practice. New York: Routledge, 2007.

HAMPEL, C. E.; LAWRENCE, T. B.; TRACEY P. Institutional Work: Taking Stock and Making it Matter. In: GREENWOOD, R.; OLIVER, C.; LAWRENCE, T. B. The SAGE Handbook of Organizational Institutionalism. 2ed, Thousand Oaks, CA: SAGE Publications, 2017.

HEAPHY, E.D. Repairing breaches with rules: Maintaining institutions in the face of everyday disruptions. Organization Science, v. 24, n. 5, p. 1291-1315, 2013.

HWANG, H.; COLYVAS, J. A. Problematizing actors and institutions in institutional work. Journal of Management Inquiry, v. 20, n. 1, p. 62-66, 2011. 
JACOMETTI, M.; GONÇALVES, S.; DE CASTRO, M. Institutional work e conhecimento em redes interorganizacionais: uma proposta para investigar APLs. RAM. Revista de Administração Mackenzie, v. 15, n. 6, 2014.

JEPPERSON, R. L. Institutions, institutional effects, and institutionalism. In: POWELL, W. W.; DIMAGGIO, P. J. (Eds.) The New Institutionalism in Organizational Analysis. Chicago: The University of Chicago Press. p. 143-163, 1991.

JESSON, J.; MATHESON, L.; LACEY, F. M. Doing your literature review: Traditional and systematic techniques. London: Sage, 2011.

KARAM, C.M.; JAMALI, D. Gendering CSR in the Arab Middle East: an institutional perspective. Business Ethics Quarterly, v. 23, n. 1, p. 31-68, 2013.

KOSKELA-HUOTARI, K. et al. Innovation in service ecosystems - Breaking, making, and maintaining institutionalized rules of resource integration. Journal of Business Research, $v$. 69, n. 8, p. 2964-2971, 2016.

KOZINETS, R. V. Netnography: Doing ethnographic research online. London: Sage publications, 2010.

KUHN, T. S. The structure of scientific revolutions. Chicago, USA: University of Chicago Press, 1962.

LANDAU, D.; DRORI, I.; TERJESEN, S. Multiple legitimacy narratives and planned organizational change. Human Relations, v. 67, n. 11, p. 1321-1345, 2014.

LANGLEY, A. Strategies for theorizing from process data. Academy of Management review, v. 24, n. 4, p. 691-710, 1999.

LATOUR, B. On actor-network theory: A few clarifications. Soziale welt, p. 369-381, 1996.

LAWRENCE, T. B.; DOVER, G. Place and institutional work: Creating housing for the hard-to-house. Administrative Science Quarterly, v. 60, n. 3, p. 371-410, 2015.

LAWRENCE, T. B.; LECA, B.; ZILBER, T. B. Institutional work: Current research, new directions and overlooked issues. Organization Studies, v. 34, n. 8, p. 1023-1033, 2013.

LAWRENCE, T. B.; SUDDABY, R. Institutions and Institutional Work. In: CLEGG, S. et al. The SAGE Handbook of Organization Studies. London: SAGE Publishing, 2006.

LAWRENCE, T.; SUDDABY, R.; LECA, B. Institutional work: Refocusing institutional studies of organization. Journal of Management Inquiry, v. 20, n. 1, p. 52-58, 2011.

. (ed.). Institutional work: Actors and agency in institutional studies of organizations. Cambridge University Press, 2009.

LEONEL JUNIOR, R.; CUNHA, C. Atores, trabalho institucional e a institucionalização da estratégia de diversificação em uma cooperativa agroindustrial. Revista Base (Administração e Contabilidade), São Leopoldo, Unisinos, v. 10, n. 1, 2013.

LOCKE, K. Field research practice in management and organization studies: Reclaiming its tradition of discovery. Academy of Management Annals, v. 5, n. 1, p. 613-652, 2011.

LUHMANN, N. Differentiation of society. Canadian Journal of Sociology/Cahiers canadiens de sociologie, p. 29-53, 1977. 
MALSCH, B.; GENDRON, Y. Re-theorizing change: Institutional experimentation and the struggle for domination in the field of public accounting. Journal of Management Studies, v. 50, n. 5, p. 870-899, 2013.

MARTINEZ-MOYANO, I. J.; MCCAFFREY, D. P.; OLIVA, R. Drift and adjustment in organizational rule compliance: explaining the "regulatory pendulum" in financial markets. Organization Science, v. 25, n. 2, p. 321-338, 2013.

MCCANN, L. et al. Still blue-collar after all these years? An ethnography of the professionalization of emergency ambulance work. Journal of Management Studies, v. 50, n. 5, p. 750-776, 2013.

MEYER, J.W.; ROWAN, B. Institutionalized organizations: Formal structure as myth and ceremony. American journal of sociology, v. 83, n. 2, p. 340-363, 1977.

MIRANDA, L. O.; CALMON, P. C. Institutional Change in Brazilian Public Administration: The case of the Ombudsman's Offices in Federal Regulatory Agencies. Organizações \& Sociedade, v. 23, n. 79, p. 571-589, 2016.

MONTEIRO, P.; NICOLINI, D. Recovering materiality in institutional work: Prizes as an assemblage of human and material entities. Journal of Management Inquiry, v. 24, n. 1, p. 61-81, 2015.

PAROUTIS, S.; HERACLEOUS, L. Discourse revisited: Dimensions and employment of first-order strategy discourse during institutional adoption. Strategic Management Journal, v. 34, n. 8, p. 935-956, 2013.

PEDROSO, J. P. P.; MASSUKADO-NAKATANI, M. S.; MUSSI, F. B. A relação entre o jeitinho brasileiro e o perfil empreendedor: possíveis interfaces no contexto da atividade empreendedora no Brasil. Revista de Administração Mackenzie, v. 10, n. 4, art. 58, p. 100-130, 2009.

RAVIOLA, E.; NORBÄCK, M. Bringing technology and meaning into institutional work: Making news at an Italian business newspaper. Organization Studies, v. 34, n. 8, p. 11711194, 2013.

RIBEIRO, R. B. et al. Estrutura de Capital, Internacionalização e Países de Destino de Empresas Brasileiras: Uma Análise da Hipótese Upstream-Downstream. Brazilian Business Review, v. 14, n. 6, p. 575-591, 2017.

ROLDÃO, T. et al. A Influência da Recessão Econômica na Intenção de Empreender: Uma Análise Cross-Country Baseada na Crise do Subprime. Organizações \& Sociedade, v. 25, n. 85, p. 320-338, 2018.

SANDER, J. A.; CUNHA, C. Atores sociais e campo organizacional: estratégias discursivas e de mobilização de recursos na construção do complexo avícola na cooperativa agroindustrial copagril. RAM - Revista de Administração Mackenzie, v. 14, n. 4, 2013.

SELZNICK, P. Foundations of the theory of organization. American sociological review, v. 13, n. 1, p. 25-35, 1948.

SEURING, S.; GOLD, S. Conducting content-analysis based literature reviews in supply chain management. Supply Chain Management: An International Journal, v. 17, n. 5, p. 544-555, 2012. 
SINGH, J.; JAYANTI, R. K. When institutional work backfires: Organizational control of professional work in the pharmaceutical industry. Journal of Management Studies, v. 50, n. 5, p. 900-929, 2013.

SILVA, M. M.; MARTINS, M. R. Financiamento orientado à construção naval no Brasil: discutindo o sistema a partir da percepção de empresas e entidades classistas. Revista de Administração e Inovação, v. 4, n. 2, p. 133-149, 2007.

SILVA, A. H. C. et al. Evolução do Controle Interno no Setor Público: Um Estudo dos Novos Normativos Emitidos entre 2003-2016. Revista de Contabilidade do Mestrado em Ciências Contábeis da UERJ, v. 22, n. 2, p. 20-38, 2017.

SILVEIRA, A. D. et al. Análise do Sistema Nacional de Inovação no setor de energia na perspectiva das políticas públicas brasileiras. Cadernos EBAPE.BR, v. 14, n. Edição Especial, p. 506-526, 2016.

SLAGER, R.; GOND, J-P.; MOON, J. Standardization as institutional work: The regulatory power of a responsible investment standard. Organization Studies, v. 33, n. 5-6, p. 763790, 2012.

SOUZA, F. J. B.; SILVA, S.A.M. Orçamento Participativo: Mais Qualidade da Democracia?. Organizações \& Sociedade, v. 24, n. 81, p. 195-215, 2017.

STYHRE, A. Gender equality as institutional work: The case of the Church of Sweden. Gender, Work \& Organization, v. 21, n. 2, p. 105-120, 2014.

SUDDABY, R. Challenges for institutional theory. Journal of Management Inquiry, v. 19, n. 1, p. 14-20, 2010.

SZNITOWSKI, A. M.; SOUZA, Y. S. Capacidade de Assimilação de Conhecimentos e Tecnologias no Setor Primário: estudo de Casos em Grandes Propriedades Rurais Produtoras de Soja. Organizações Rurais \& Agroindustriais, v. 18, n. 2, p. 171-185, 2016.

INTERNATIONAL TRANSPARENCY. Corruption Perceptions index 2017. Available in: https://www.transparency.org/news/feature/corruption_perceptions_index_2017.

TURETA, C.; JÚLIO, A. C. Estratégia Como Prática Social e Trabalho Institucional: Uma Proposta De Articulação Teórica. TPA-Teoria e Prática em Administração, v. 6, n. 2, p. 26-53, 2016.

VIEIRA, C. A.; COSTA, F. L.; BARBOSA, L. O. O'jeitinho'brasileiro como recurso de poder. Revista de Administração Pública, v. 16, p. 5-31, 1982.

WILLMOTT, H. "Institutional work" for what? Problems and prospects of institutional theory. Journal of Management Inquiry, v. 20, n. 1, p. 67-72, 2011.

YIN, R.K. Estudo de Caso: Planejamento e Métodos. Porto Alegre: Bookman, 2015.

ZIETSMA, C.; LAWRENCE, T. B. Institutional work in the transformation of an organizational field: The interplay of boundary work and practice work. Administrative Science Quarterly, v. 55, n. 2, p. 189-221, 2010.

ZUCKER, L. G. The role of institutionalization in cultural persistence. American sociological review, p. 726-743, 1977. 
ZUNDEL, M.; HOLT, R.; CORNELISSEN, J. Institutional work in The Wire: An ethological investigation of flexibility in organizational adaptation. Journal of Management Inquiry, $v$. 22, n. 1, p. 102-120, 2013.

Data de Submissão: 19/07/2017.

Data de Aprovação: 18/06/2018. 